Rana Fathinah: Pengaruh Capital Adequacy Ratio Dan Non Performing | 423

\title{
PENGARUH CAPITAL ADEQUACY RATIO DAN NON PERFORMING FINANCING TERHADAP PROFITABILITAS BANK UMUM SYARIAH DI INDONESIA
}

\author{
Rana Fathinah Ananda \\ Universitas Medan Area \\ ranafathinahananda@gmail.com
}

\begin{abstract}
Penelitian ini bertujuan untuk mengetahui dan menganalisis apakah Capital Adequacy Ratio dan Non Performing Financing berpengaruh baik secara simultan dan parsial terhadap Profitabilitas pada Bank Umum Syariah di Indonesia. Populasi dan sampel penelitian ini, yaitu Bank Umum Syariah Indonesia yang terdaftar di Bank Indonesia periode 2010-2019, yaitu sebanyak 13 perusahaan dengan teknik pengambilan sampel jenuh sehingga didapat 13 perusahaan. Analisis data dalam penelitian ini adalah analisis kuantitatif dengan metode analisis data yang digunakan dalam penelitian ini menggunakan analisis regresi linear berganda dan pemilihan regresi data panel dengan melakukan uji chow, uji hausmant, dan uji lagrange multiplier dengan menggunakan aplikasi Eviews. Hasil penelitian secara simultan menunjukkan Capital Adequacy Ratio dan Non Performing Financing berpengaruh signifikan terhadap Profitabilitas. Secara parsial, hasil uji hipotesis menunjukkan bahwa variabel Capital Adequacy Ratio berpengaruh positif namun tidak signifikan terhadap ROA pada bank Umum Syariah di Indonesia, sedangkan Non Performing Financing berpengaruh negatif signifikan terhadap Probabilitas pada bank Umum Syariah di Indonesia.

Kata kunci: Bank Syariah, Capital Adequacy Ratio, Non Performing Financing, Profitabilitas
\end{abstract}

\begin{abstract}
This study is aimed to analyze and determined whether the Capital Adequacy Ratio and Non Performing Financing effect simultaneously and partially on the Profitability of Islamic Banks in Indonesia. The population and sample of this research are the Indonesian Sharia Banks which are registered in Bank Indonesia for the year from 2010 until 2019, as many as 13 Banks with saturated sampling techniques in order to obtain 13 Banks. The data analysis in this research is quantitative analysis with the data analysis method used in this study using multiple linear regression analysis and panel data regression selection by doing the Chow test, Hausmant test and Lagrange Multiplier test using Eviews software. The results of this research shows that simultaneously the Capital Adequacy Ratio and NonPerforming Financing, both have a significant effect on Profitability. Partially, the results of the hypothesis test show that the Capital Adequacy Ratio variable has a positive but insignificant effect on ROA in IslamicBanks in Indonesia, while Non Performing Financing has a significant negative effect on the Probability of IslamicBanks in Indonesia.
\end{abstract}


424 AT-TAWASSUTH: Jurnal Ekonomi Islam, Volume V No. 2

Juli - Desember 2020: 423 - 442

Keywords: Capital Adequacy Ratio, Islamic Banks, Non Performing Financing, Profitability

\section{Pendahuluan}

Modal merupakan suatu elemen penting yang sangat dibutuhkan daalam rangka melakukan kegiatan bisnis. Pada bisnis yang besar, kebutuhan dana juga cukup besar, sehingga sebagian besar pelaku bisnis bekerjasama dengan pihak bank untuk mendapatkan dana atau pinjaman. Pihak bank berperan sebagai lembaga intermediasi antara bank dan masyarakat, yaitu menghimpun dana dari masyarakat dan disalurkan kembali kepada masyarakat untuk kegiatan yang dapat meningkatkan taraf hidup.

Perbankan di Indonesia terdapat dua jenis bank, yaitu bank syariah dan bank konvensional. Kedua bank tersebut memiliki banyak perbedaan, baik itu dari segi bank dalam mendapatkan keuntungan, sistem operasional bank, pengelolaan dana bank, metode transaksi, denda keterlambatan serta dari proses perjanjiannya. Perkembangan kedua jenis bank ini sangat pesat seiring dengan perkebangan zaman. Perkembangan kelembagaan perbankan syariah sendiri semakin meningkat sejak dikeluarkannya Undang-Undang No. 7 Tahun 1992 tentang perbankan.

Keberadaan bank syariah ditengah-tengah perbankan konvesional adalah untuk menawarkan sistem perbankan bagi umat islam yang membutuhkan.Dengan progres perkembangannya yang impresif, yang mencapai rata-rata pertumbuhan aset lebih dari $65 \%$ pertahun dalam lima tahun terakhir, maka diharapkan peran industri perbankan syariah dalam mendukung perekonomian nasional akan semakin signifikan (OJK, 2019). ${ }^{1}$ Pertumbuhan aset tersebut menunjukkan bahwa Bank Umum Syariah di Indonesia berkembang dengan pesat. Namun yang menjadi kontroversi adalah adanya fenomena bahwa Bank Umum Syariah memiliki nilai ROA yang lebih rendah dibanding Bank Umum Konvensional. Untuk melihat profitabilitas Bank Umum Syariah dan Bank Umum Konvensional berikut disajikan nilai return on asset (ROA) selama kurun waktu 5 tahun berturut-turut. 
Rana Fathinah: Pengaruh Capital Adequacy Ratio Dan Non Performing | 425

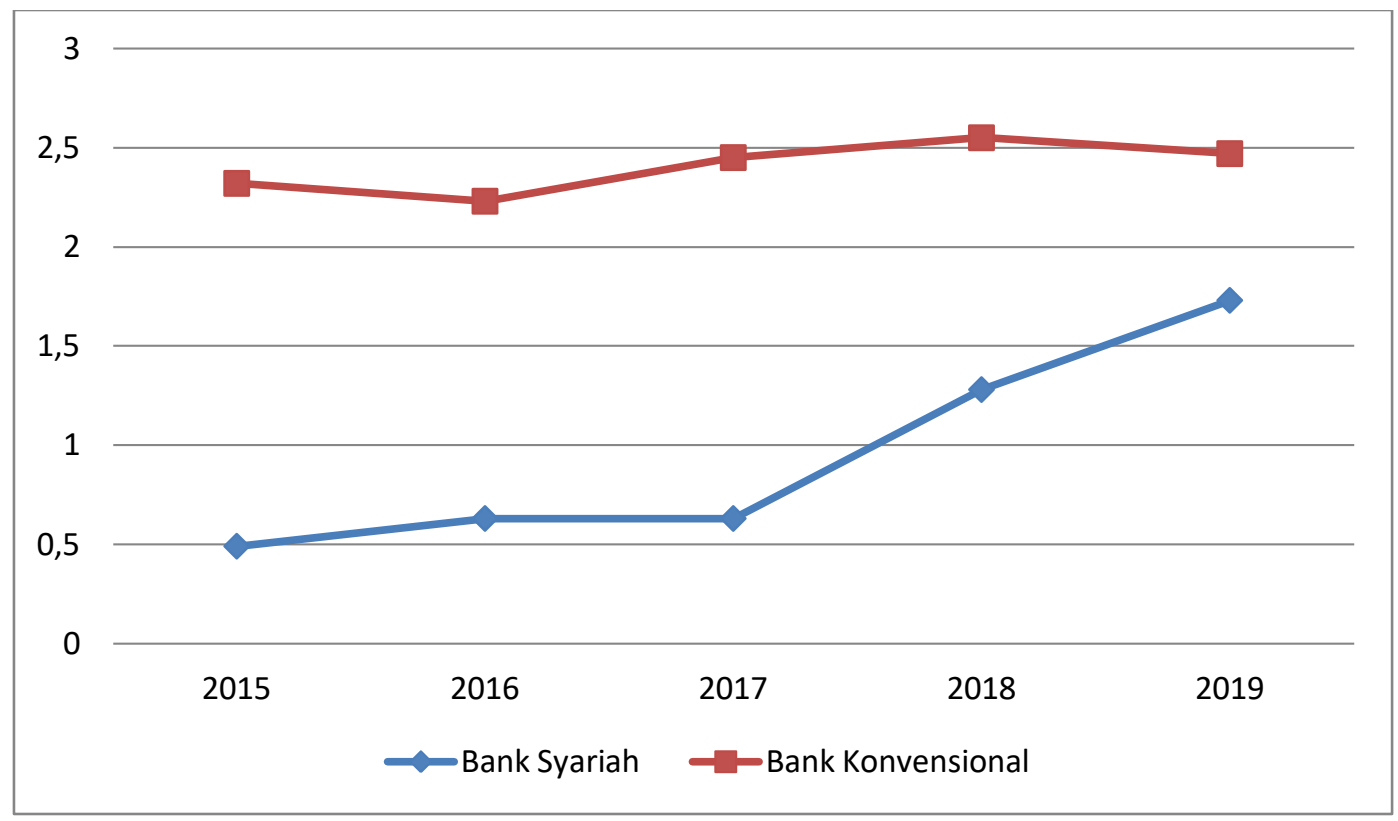

Sumber : Statistik Perbankan Syariah OJK per Desember 2019

Gambar 1 Profitabilitas Bank Umum Konvensional dan Bank Umum Syariah

Tahun 2015-2019 Berdasarkan ROA (\%)

Gambar diatas memperlihatkan perubahan angka dari rasio profitabilitas yang dicapai Bank Umum Konvensional dan Bank Umum Syariah menggunakan indikator ROA (Return On Asset) yang diperoleh dari tahun 2015-2019.

Nilai ROA pada Bank Umum Syariah pada tahun 2015 sebesar 0,49\% dan naik pada tahun 2016 sebesar 0,63\% kemudian di tahun 2017 masih sama dengan tahun sebelumnya sebesar $0,63 \%$, lalu pada tahun 2018 meningkat mnjadi 1,28\% dan kembali meningkat pada tahun 2019 sebesar 1,73\%. Angka tersebut sudah termasuk dalam kriteria yang sehat dimana kriteria yang ditetapkan Bank Indonesia (BI) mengenai tingkat kesehatan faktor earning yaitu $\mathrm{ROA}>1,5 \%$.

Gambar 1 juga memperlihatkan nilai ROA Bank Umum Konvensional pada tahun 2015 sebesar 2,32\% kemudian mengalami penurunan di tahun 2016 menjadi 2,23\%, lalu meningkat kembali di tahun 2017 sebesar 2,45\% dan 2,55\% di tahun 2018, tetapi kembali mengalami penurunan di tahun 2019 menjadi 2,47\%. Walaupun ROA pada Bank Umum Konvensional mengalami penurunan pada tahun 2016 dan 2019, namun ROA pada Bank Umum Syariah lebih rendah dibanding Bank Umum Konvensional. Hal ini berarti Bank Umum Konvensional memiliki profitabilitas yang 
426 |AT-TAWASSUTH: Jurnal Ekonomi Islam, Volume V No. 2

Juli - Desember 2020: 423 - 442

lebih baik dalam penggunaan dan pengolahan aset yang dimiliki untuk menghasilkan keuntungan.

Nilai ROA pada Bank Umum Syariah menunjukkan bahwa bank umum syariah di Indonesia kurang baik dalam mengelola aset yang dimiliki untuk menghasilkan laba. Penurunan ROA di perbankan syariah Indonesia tentu akan berdampak pada penurunan pendapatan laba industri perbankan di Indonesia. Terdapat sejumlah sebab menurunnya tingkat pertumbuhan bank selama beberapa tahun terakhir, yaitu seperti faktor besar kecilnya aset, sampai sulitnya perbankan dalam mendapatkan nasabah pembiayaan. ${ }^{2}$

Profitabilitas bank syariah yang lebih rendah dibandingkan bank konvensional, disebabkan karena biaya operasional yang lebih tinggi dan pembiayaan bermasalah yang meningkat.Produk-produk pembiayaan di dalam perbankan syariah tentunya akan memberikan keuntungan bagi pihak bank. Dalam penggunaan assetnya serta operasional bank syariah sama halnya dengan bank konvensional yaitu berfungsi untuk mengerahkan dana dari masyarakat dan menyalurkan kembali danadana tersebut kepada masyarakat yang membutuhkan, dengan memanfaatkan aktiva produktif yang dimiliki bank.

Rasio permodalan yang lazim digunakan untuk mengukur kesehatan bank adalah Capital Adequacy Ratio (CAR). Rasio kecukupan modal merupakan rasio yang bertujuan untuk memastikan bahwa bank dapat menyerap kerugian yang timbul dari aktivitas yang dilakukannya (Lukman, 2009). ${ }^{3}$ Rasio kecukupan modal juga akan sangat membantu dalam mempersiapkan diri untuk mengantisipasi adanya penuruan asset. Rasio kecukupan modal perbankan bertujuan untuk memelihara kesehatan bank, hal ini sangat diperlukan ketika bank dikhawatirkan akan mengalami kerugian. Dalam hal ini, bank memerlukan tingkat CAR yang besar sehingga mampu mendukung pengembangan operasi dan kelangsungan hidup bank serta menanggung segala risiko yang timbul seperti risiko kredit dan nantinya akan berdampak pada kelancaran kegiatan operasional bank dan meningkat profitabilitas bank. Peranan modal (CAR) sangat penting dalam perbankan karena dapat mendukung kegiatan operasional agar dapat dapat berjalan dengan lancar. ${ }^{4}$ 
Rana Fathinah: Pengaruh Capital Adequacy Ratio Dan Non Performing | 427

Meningkatnya produk pembiayaan dalam bank syariah akan mendatangkan resiko perbankan yang besar pula, salah satunya yaitu resiko pembiayaan. Produk investasi memiliki sifat yang senantiasa mendatangkan resiko, pembiayaan pun mengalami ketidakpastian atas pengembalian laba atau keuntungan dari dana yang telah disepakati antara bank dan nasabah. tingginya resiko pembiayaan tercemin dari rasio pembiayaan bermasalah yang sering dikenal sebagai Non Performing Financing (NPF). Pada perbankan Syariah, NPF pada akhir Maret 2019 berada pada level $3,44 \%$, sementara kredit bermasalah perbankan konvensional (NPL) berada pada level 2,5\%. Pada periode sebelumnya, pembiayaan bermasalah perbankan syariah lebih besar lagi. Contohnya pada akhir 2017 yang mencapai 4,76\% ataupun 2016 yang mencapai 4,42\%. Hal tersebut berpengaruh terhadap profitabilitas dari perbankan syariah yang tercatat hanya Rp 5,12 triliun pada periode 2018. Dengan tingkat aset sebesar Rp 316,691 triliun, maka Return On Asset (ROA) tercatat hanya 1,28\%. Sementara ROA perbankan konvensional menyentuh 2,55\% pada akhir Desember $2018 .^{5}$

Pembiayaan bermasalah (Non Performing Financing) berarti pembiayaan yang dalam pelaksanaanya belum mencapai atau memenuhi target yang diinginkan pihak bank seperti pengembalian pokok atau bagi hasil yang bermasalah. Semakin besar NPF, maka akan semakin rendah profitabilitas perbankan syariah yang dihitung dengan Return On Asset (ROA). Sebaliknya apabila semakin rendah tingkat NPF maka akan semakin tinggi tingkat profitabilitas perusahaan. Bank dengan tingkat NPF yang semakin rendah akan memiliki kemampuan menyalurkan dananya kepada nasabah lainnya sehingga tingkat profitabilitas perusahaan akan semakin meningkat. ${ }^{6}$

\section{Kajian Teori}

\section{Teori Laba Monopoli (Monopoli Theory of Profit)}

Teori ini mengatakan bahwa beberapa perusahaan dengan kekuatan monopoli dapat membatasi output dan menetapkan harga yang lebih tinggi daripada bila perusahaan beroperasi dalam kondisi persaingan sempurna. Dengan demikian perusahaan menikmati keuntungan. Perusahaan dengan kekuatan monopoli membatasi output dan membebankan harga lebih tinggi daripada di bawah persaingan 
sempurna. Ini menyebabkan keuntungan di atas normal diperoleh oleh perusahaan monopolistik.

Laba sebagai suatu alat prediktif yang membantu dalam peramalan laba mendatang dan peristiwa ekonomi yang akan datang. Nilai laba di masa lalu, yang didasarkan pada biaya historis dan nilai berjalan, terbukti berguna dalam meramalkan nilai mendatang. Laba terdiri dari hasil opersional atau laba biasa danhasil-hasil nonoperasional atau keuntungan dan kerugian luar biasa di mana jumlah keseluruhannya sama dengan laba bersih. Laba bisa dipandang sebagai suatu ukuran efisiensi.Laba adalah suatu ukuran kepengurusan (stewardship) manajemen atas sumberdaya suatu kesatuan dan ukuran efisiensi manajemen dalam menjalankan usaha suatu perusahaan.

\section{Teori Sinyal (Signaling Theory)}

Signaling theory mengemukakan tentang bagaimana seharusnya sebuah perusahaan memberikan sinyal kepada pengguna laporan keuangan. Sinyal ini berupa informasi mengenai apa yang sudah dilakukan manajemen untuk merealisasi kan pemilik. Sinyal dapat promosi atau informasi lain yang menyatakan bahwa perusahaan tersebut baik daripada perusahaan lain (Jama'an, 2008).

Penggunaan teori signalling, informasi berupa ROA atau tingkat pengembalian terhadap aset atau juga seberapa besar laba yang didapat dari aset yang digunakan, dengan demikian jika ROA tinggi maka akan menjadi sinyal yang baik bagi para investor, karena dengan ROA tinggi menunjukkan kinerja perusahaan tersebut baik maka investor akan tertarik untuk menginvestasikan dananya yang berupa surat berharga atau saham. Permintaan saham yang banyak maka harga saham akan meningkat. Profitabilitas yang tinggi menunjukkan prospek perusahaan baik, sehingga investor akan merespon positif sinyal tersebut dan nilai perusahaan akan meningkat.

\section{Profitabilitas}

Profitabilitas (keuntungan) merupakan hasil darikebijaksanaan yang diambil oleh manajemen. Rasio keuntungan untuk mengukur seberapa besar tingkat keuntungan yang dapatdiperoleh oleh perusahaan.Semakin besar tingkat keuntungan menunjukkan semakin baik manajemen dalam mengelola perusahaan. ${ }^{7}$ Profitabilitas 
Rana Fathinah: Pengaruh Capital Adequacy Ratio Dan Non Performing |429

adalah ukuran spesifik dari performance sebuah bank, dimana ia merupakan tujuan dari manajemen perusahaan dengan memaksimalkan nilai dari para pemegang saham, optimalisasi dari berbagai tingkat return dan minimalisasi resiko yang ada. Kemampuan ini dilakukan dalam suatu periode.

Bank yang sehat adalah bank yang diukur secara profitabilitas atau rentabilitas yang terus meningkat diatas standar yang ditetapkan. Return on Asset (ROA) adalah salah satu rasio yang digunakan untuk mengukur kemampuan manajemen bank dalam memperoleh keuntungan (laba) secara keseluruhan.

Rasio ini menggambarkan perputaran aktiva diukur dari volume penjualan. Semakin besar rasio ini semakin baik.Hal ini berarti bahwa aktiva dapat lebih cepat berputar dan memperoleh laba.

Tabel 1 Kriteria Kesehatan ROA

\begin{tabular}{ccc}
\hline Peringkat & Keterangan & Kriteria \\
\hline 1 & Sangat Sehat & ROA $>1,5 \%$ \\
\hline 2 & Sehat & $1.25 \%<\mathrm{ROA} \leq 1,5 \%$ \\
\hline 3 & Cukup Sehat & $0,5 \%<\mathrm{ROA} \leq 1,25 \%$ \\
\hline 4 & Kurang Sehat & $0 \%<\mathrm{ROA} \leq 0,5 \%$ \\
\hline 5 & Tidak Sehat & $\mathrm{ROA} \leq 0 \%$
\end{tabular}

Sumber : Surat Edaran Bank Indonesia No. 9/24/DPbs Tahun 2007

\section{Capital Adequacy Ratio (CAR)}

CAR merupakan rasio kecukupan modal yang harus disediakan untukmenjamin dana deposan. Tujuannya adalah agarlikuiditas/kemampuan bank membayar kepada deposan cukupterjamin. Modal merupakan salah satu faktor penting dalamrangka pengembangan usaha bisnis dan menampung resiko kerugian, semakin tinggi CAR maka semakin kuatkemampuan bank tersebut untuk menanggung resiko darisetiap kredit/aktiva produktif yang berisiko.

Rasio kecukupan modal bank dapat dibandingkan dengan kewajiban penyediaan modal minimum (yakni sebesar 8\%). Berdasarkan perbandingan tersebut, dapatlah diketahui apakah bank yang bersangkutan telah memenuhiketentuan kecukupan modal atau tidak. Semakin tinggi CAR maka semakin kuat kemampuan bank tersebut untuk menanggung risiko dari setiap kredit/ aktiva produktif yang 
430 AT-TAWASSUTH: Jurnal Ekonomi Islam, Volume V No. 2

Juli - Desember 2020: 423 - 442

berisiko. Modal disini meliputi: modal disetor maupun dana setoran modal, cadangan umum, cadangan lainnya, sisa laba tahun lalu, dan laba tahun berjalan.

Tabel 2 Kriteria Kesehatan CAR

\begin{tabular}{ccc}
\hline Peringkat & Keterangan & Kriteria \\
\hline 1 & Sangat Sehat & CAR $>12 \%$ \\
\hline 2 & Sehat & $9 \% \leq$ CAR $<12 \%$ \\
\hline 3 & Cukup Sehat & $8 \% \leq$ CAR $<9 \%$ \\
\hline 4 & Kurang Sehat & $6 \%<$ CAR $<8 \%$ \\
\hline 5 & Tidak Sehat & CAR $\leq 6 \%$ \\
\hline
\end{tabular}

Sumber : Surat Edaran Bank Indonesia No. 9/24/DPbs Tahun 2007

\section{Non Performing Financing (NPF)}

Non Performing Loan (NPL) pada bank konvensional atau pada bank Syariah disebut Non Performing Financing (NPF), merupakan rasio keuangan yang berkaitan dengan risiko pembiayaan yang diberikan oleh bank, sehingga rasio inimenunjukkan kemampuan manajemen bank dalam mengelola pembiayaan bermasalah yang diberikan oleh bank kepada nasabah. Pembiayaan bank menurut kualitasnya pada hakikatnya didasarkan atas risiko kemungkinan menurut bank terhadap kondisi dan kepatuhan nasabah pembiayaan dalam memenuhi kewajiban-kewajiban untuk membayar bagi hasil, mengangsur, serta melunasi pembiayaan kepada bank (Rivai, 2013). ${ }^{8}$ Semakin tinggi rasio NPF maka semakin buruk kualitas kredit bank yang menyebabkan jumlah kredit bermasalah semakin besar, maka kemungkinan suatu bank dalam kondisi bermasalah semakin besar. Rasio NPF ini dapat dibandingkan dengan kriteria kesehatan NPF bank syariah yang ditetapkan oleh Bank Indonesia seperti yang tertera dalam tabel berikut.

Tabel 3 Kriteria Kesehatan Non Performing Financing (NPF)

\begin{tabular}{cll}
\hline No. & \multicolumn{1}{c}{ Nilai NPF } & \multicolumn{1}{c}{ Predikat } \\
\hline 1 & $\mathrm{NPF}>2 \%$ & Sehat \\
\hline 2 & $2 \% \leq \mathrm{NPF} \leq 8 \%$ & Sehat \\
\hline 3 & $5 \% \leq \mathrm{NPF} \leq 8 \%$ & Cukup Sehat \\
\hline 4 & $8 \% \leq \mathrm{NPF} \leq 12 \%$ & Kurang Sehat \\
\hline
\end{tabular}


Rana Fathinah: Pengaruh Capital Adequacy Ratio Dan Non Performing |431

Sumber : Surat Edaran Bank Indonesia No. 9/24/DPbs Tahun 2007

\section{Metode Penelitian}

Jenis data yang digunakan adalah data kuantitatif dengan sumber data yang digunakan adalah data sekunder yaitu data yang diperoleh dalam bentuk yang sudah jadi dan diambil langsung dari Bank Indonesia. Jenis data yang diambil dalam penelitian ini adalah time series dan cros section atau sering disebut dengan data panel. Populasi dan sampel penelitian ini yaitu Bank Umum Syariah Indonesia yang terdaftar di Bank Indonesia periode 2010-2019.

Tabel 4 Populasi dan Sampel Penelitian

\begin{tabular}{cl}
\hline No. & Nama Bank Syariah \\
\hline 1 & PT. Bank Aceh \\
\hline 2 & PT. Bank Muamalat Indonesia \\
\hline 3 & PT. Bank Victoria Syariah \\
\hline 4 & PT. Bank BRI Syariah \\
\hline 5 & PT. Bank Jabar Banten Syariah \\
\hline 7 & PT. Bank BNI Syariah \\
\hline 8 & PT. Bank Syariah Mandiri \\
\hline 9 & PT. Bank Panin Syariah \\
\hline 10 & PT. Bank Syariah Bukopin \\
\hline 11 & PT. BCA Syariah \\
\hline 12 & PT. Maybank Syariah Indonesia \\
\hline 13 & PT. Bank Tabungan Pensiunan Nasional Syariah
\end{tabular}

Sumber : Statistik Perbankan Syariah OJK per Desember 2017

Dalam penelitian ini terdapat tiga variabel, dimana variabel independen yaitu Capital Adequacy Ratio (CAR)dan Non Performing Financing (NPF) sebagai variabel (X), dan variabel Profitabilitas sebagai variabel (Y). 
432 AT-TAWASSUTH: Jurnal Ekonomi Islam, Volume V No. 2

Juli - Desember 2020: 423 - 442

Tabel 5 Tabel Pengukuran Operasional Variabel-Variabel Penelitian

\begin{tabular}{|c|c|c|c|}
\hline Variabel & Definisi & $\begin{array}{c}\text { Indikator } \\
\text { Pengukuran } \\
\text { Variabel }\end{array}$ & Skala \\
\hline Profitabilitas & $\begin{array}{lr}\text { Profitabilitas } & \text { bank } \\
\text { merupakan } & \text { suatu } \\
\text { kemampuan bank } & \text { dalam } \\
\text { menghasilkan } & \text { laba. } \\
\text { Profirabilitas } & \text { dalam } \\
\text { penelitian ini diukur } & \text { dio } \\
\text { menggunakan rasio ROA. }\end{array}$ & $\begin{array}{c}\text { ROA }=\frac{\text { LaaBersih }}{\text { TotalAsset }} \mathrm{x} \\
100 \%\end{array}$ & Rasio \\
\hline $\begin{array}{l}\text { Capital } \\
\text { Adequacy } \\
\text { Ratio } \\
\text { (CAR) }\end{array}$ & $\begin{array}{lr}\text { CAR adalah } & \text { rasio } \\
\text { kecukupan modal } & \text { yang } \\
\text { harus } & \text { disediakan } \\
\text { untukmenjamin } & \text { dana } \\
\text { deposan. }\end{array}$ & $\begin{array}{c}C A R=\frac{\text { ModalSendiri }}{A T M R} \times \\
100 \%\end{array}$ & Rasio \\
\hline $\begin{array}{l}\text { Non } \\
\text { Performing } \\
\text { Financing } \\
(\mathrm{NPF})\end{array}$ & $\begin{array}{l}\text { Rasio perbandingan antara } \\
\text { pembiayaan bermasalah } \\
\text { yang terdiri dari } \\
\text { pembiayaan kurang lancar, } \\
\text { diragukan dan macet dengan } \\
\text { total pembiayaan yang } \\
\text { disalurkan. }\end{array}$ & $\begin{array}{c}N P F= \\
\frac{\text { PembiayaanBermasalah }}{\text { TotalPembiayaan }} \\
\times 100 \%\end{array}$ & Rasio \\
\hline
\end{tabular}

Analisis data dalam penelitian ini adalah analisis kuantitatif dengan metode analisis data yang digunakan dalam penelitian ini menggunakan analisis regresi linear berganda dan pemilihan regresi data panel dengan melakukan uji chow uji hausmant, dan uji lagrange multiplier dengan menggunakan aplikasi Eviews.Pengujian hipotesis penelitian dilakukan melalui uji koefisien determinasi $\left(\mathrm{R}^{2}\right)$, uji statistik F (Fishier), dan uji statistik t. 
Rana Fathinah: Pengaruh Capital Adequacy Ratio Dan Non Performing |433

Tujuan penelitian ini adalah untuk mengetahui dan menganalisis pengaruh Capital Adequacy Ratio(CAR) dan Non Performing Financing(NPF) secara simultan terhadap Profitabilitas (Return On Asset / ROA) pada perusahaan perbankan syariah, untuk mengetahui dan menganalisis pengaruh Capital Adequacy Ratio dan Non Performing Financing masing-masing secara parsial terhadap profitabilitas.

Kerangka konseptual menjelaskan Capital Adequacy Ratio(CAR) dan Non Perfoming Financing (NPF) mempengaruhi profitabilitasseperti pada gambar 2 berikut.

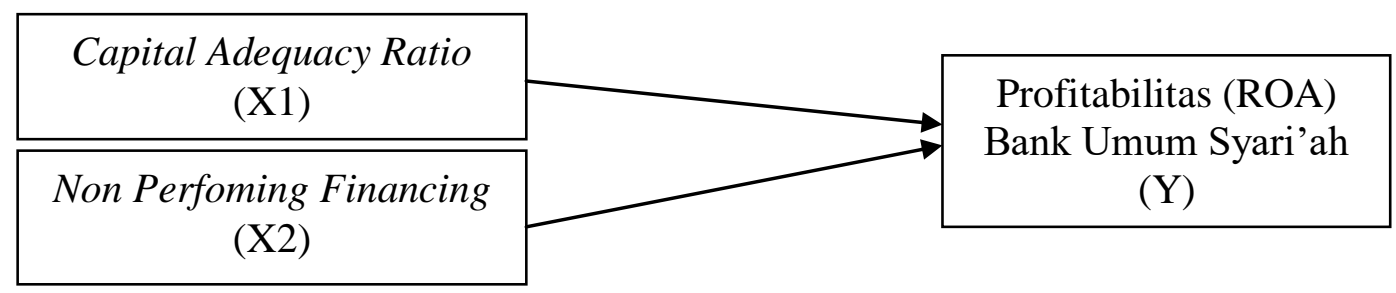

Gambar 2 Kerangka Konseptual

Capital Adequacy Ratio (CAR) adalah rasio yang memperlihatkan seberapajauh seluruh aktiva bank yang mengandung resiko (kredit, penyertaan, surat berharga, tagihan pada bank lain) ikut dibiayai dari dana modal sendiri bank di samping memperoleh dana-dana dari sumber-sumber di luar bank seperti dana masyarakat, pinjaman (utang), dan lain-lain. Dengan kata lain CAR adalah rasio kinerja bank untuk mengukur kecukupan modal yang dimiliki bank untuk menunjang aktiva yang mengandung atau menghasilkan risiko. Semakin besar CAR maka semakin besar juga kredit yang dapat disalurkan, sehingga dapat meningkatkan laba bank yang kemudian akan meningkatkan tingkat profitabilitas bank tersebut. ${ }^{9}$

Jenis data yang digunakan adalah data kuantitatif dengan sumber data yang digunakan adalah data sekunder yaitu data yang diperoleh dalam bentuk yang sudah jadi dan diambil langsung dari Bank Indonesia. Jenis data yang diambil dalam penelitian ini adalah time series dan cros section atau sering disebut dengan data panel. Populasi dan sampel penelitian ini yaitu Bank Umum Syariah Indonesia yang terdaftar di Bank Indonesia periode 2010-2019.

Tabel 4 Populasi dan Sampel Penelitian

\section{No. Nama Bank Syariah}


AT-TAWASSUTH: Jurnal Ekonomi Islam, Volume V No. 2

Juli - Desember 2020: 423 - 442

\begin{tabular}{ll}
\hline 1 & PT. Bank Aceh \\
\hline 2 & PT. Bank Muamalat Indonesia \\
\hline 3 & PT. Bank Victoria Syariah \\
\hline 4 & PT. Bank BRI Syariah \\
\hline 5 & PT. Bank Jabar Banten Syariah \\
\hline 6 & PT. Bank BNI Syariah \\
\hline 8 & PT. Bank Syariah Mandiri \\
\hline 10 & PT. Bank Mega Syariah \\
\hline 11 & PT. Bank Panin Syariah \\
\hline 12 & PT. BCA Sank Syariah Bukopin \\
\hline 13 & PT. Bank Tabungan Pensiunan Nasional Syariah \\
\hline
\end{tabular}

Sumber : Statistik Perbankan Syariah OJK per Desember 2017

Dalam penelitian ini terdapat tiga variabel, dimana variabel independen yaitu Capital Adequacy Ratio (CAR)dan Non Performing Financing (NPF) sebagai variabel $(\mathrm{X})$, dan variabel Profitabilitas sebagai variabel (Y).

Tabel 5 Tabel Pengukuran Operasional Variabel-Variabel Penelitian

\begin{tabular}{|c|c|c|c|c|}
\hline Variabel & Definisi & & $\begin{array}{c}\text { Indikator } \\
\text { Pengukuran } \\
\text { Variabel } \\
\end{array}$ & Skala \\
\hline Profitabilitas & $\begin{array}{l}\text { Profitabilitas } \\
\text { merupakan } \\
\text { kemampuan bank } \\
\text { menghasilkan } \\
\text { Profirabilitas } \\
\text { penelitian ini } \\
\text { menggunakan rasio }\end{array}$ & $\begin{array}{r}\text { bank } \\
\text { suatu } \\
\text { dalam } \\
\text { laba. } \\
\text { dalam } \\
\text { diukur } \\
\text { OA. }\end{array}$ & $\begin{array}{c}R O A=\frac{\text { LaaBersih }}{\text { TotalAsset }} \mathrm{x} \\
100 \%\end{array}$ & Rasio \\
\hline
\end{tabular}


Rana Fathinah: Pengaruh Capital Adequacy Ratio Dan Non Performing | 435

\begin{tabular}{|c|c|c|c|}
\hline Capital & adalah & \multirow[b]{2}{*}{$\begin{array}{c}C A R=\frac{\text { ModalSendiri }}{A T M R} \times \\
100 \%\end{array}$} & \multirow[b]{2}{*}{ Rasio } \\
\hline $\begin{array}{l}\text { Adequacy } \\
\text { Ratio } \\
\text { (CAR) }\end{array}$ & $\begin{array}{lr}\text { kecukupan modal yang } \\
\text { harus } & \text { disediakan } \\
\text { untukmenjamin } & \text { dana } \\
\text { deposan. }\end{array}$ & & \\
\hline Non & Rasio perbandingan antara & & \multirow{4}{*}{ Rasio } \\
\hline Performing & pembiayaan & $N P F=$ & \\
\hline $\begin{array}{l}\text { Financing } \\
(\mathrm{NPF})\end{array}$ & $\begin{array}{l}\text { yang terdiri dari } \\
\text { pembiayaan kurang lancar, } \\
\text { diragukan dan macet dengan }\end{array}$ & $\begin{array}{c}\frac{\text { PembiayaanBermasalah }}{\text { TotalPembiayaan }} \\
\text { x } 100 \%\end{array}$ & \\
\hline & $\begin{array}{l}\text { total pembiayaan yang } \\
\text { disalurkan. }\end{array}$ & & \\
\hline
\end{tabular}

Analisis data dalam penelitian ini adalah analisis kuantitatif dengan metode analisis data yang digunakan dalam penelitian ini menggunakan analisis regresi linear berganda dan pemilihan regresi data panel dengan melakukan uji chows uji hausmant, dan uji lagrange multiplier dengan menggunakan aplikasi Eviews.Pengujian hipotesis penelitian dilakukan melalui uji koefisien determinasi $\left(\mathrm{R}^{2}\right)$, uji statistik F (Fishier), dan uji statistik t.

\section{Hasil dan Pembahasan}

Penentuan model estimasi antara Common Effect Model (CEM), Fixed Effect Model (FEM), dan Random Effect Model (REM), model estimasi yang terpilih untuk digunakan dalam penelitian ini adalah model common effect model (CEM). Pada model data panel jika model yang terpilih ialah common effect atau fixed effect maka uji asumsi klasik yang harus dilakukan meliputi uji heteroskedstisitas dan uji multikolinearitas, sedangkan jika model terpilih berupa random effect maka tidak perlu dilakukan uji asumsi klasik. ${ }^{10}$

\section{Uji Multikolinearitas}

Hasil uji multikolinearitas disajikan sebagai berikut: 
AT-TAWASSUTH: Jurnal Ekonomi Islam, Volume V No. 2

Juli - Desember 2020: 423 - 442

Tabel 6 Uji Multikolinearitas dengan Matriks Korelasi

\begin{tabular}{ccc}
\hline & CAR & NPF \\
\hline CAR & 1.000000 & -0.160908 \\
\hline NPF & -0.160908 & 1.000000 \\
\hline
\end{tabular}

Hasil pengujian multikolinearitas, dapat disimpulkan bahwa tidak terdapat gejala multikolinearitas antar variabel independen. Hal ini karena nilai korelasi antar variabel independen tidak lebih dari $0,9 .^{11}$

\section{Uji Heteroskedastisitas}

Deteksi ada tidaknya heteroskedastisitas dapat dilakukan dengan uji Glejser berikut.

Tabel 7 Uji Heteroskedastisitas (uji Glejser)

\begin{tabular}{ccccc}
\hline Variable & Coefficient & Std. Error & t-Statistic & Prob. \\
\hline C & 1.000494 & 0.431351 & 2.319444 & 0.0220 \\
\hline CAR & 0.013031 & 0.009500 & 1.371697 & $\mathbf{0 . 1 7 2 6}$ \\
\hline NPF & 0.148712 & 0.135677 & 1.096069 & $\mathbf{0 . 2 7 5 1}$ \\
\hline
\end{tabular}

Berdasarkan hasil uji Glejser, dapat diketahui bahwa nilai Prob. Glejser dari ROA adalah 0.1726, nilai Prob. Glejser dari NPF adalah 0.2751, sehingga diketahui seluruh nilai Prob. Glejser > 0,05 yang berarti tidak terjadi heteroskedastisitas.

\section{Pengujian Hipotesis}

Pada pengujian hipotesis, akan dilakukan analisis koefisien determinasi, pengujian pengaruh simultan (uji F), dan pengujian pengaruh parsial (uji t). Nilainilai statistik dari koefisien determinasi, uji F, dan uji t tersaji pada tabel berikut.

Tabel 8 Uji Koefisien Determinasi, Uji Simultan dan Uji Parsial

\begin{tabular}{crrrr}
\hline \hline Variable & Coefficient & Std. Error & t-Statistic & Prob. \\
\hline \hline CAR & 0.011735 & 0.011575 & 1.013825 & $\mathbf{0 . 3 1 2 6}$ \\
ROA & -0.977775 & 0.165301 & -5.915124 & $\mathbf{0 . 0 0 0 0}$ \\
C & 3.010067 & 0.525531 & 5.727663 & 0.0000 \\
\hline \hline
\end{tabular}


Rana Fathinah: Pengaruh Capital Adequacy Ratio Dan Non Performing |437

\begin{tabular}{llll} 
R-squared & 0.234732 & Mean dependent var & 1.324769 \\
Adjusted R-squared & $\mathbf{0 . 2 2 2 6 8 1}$ & S.D. dependent var & 3.291446 \\
S.E. of regression & 2.901926 & Akaike info criterion & 4.991433 \\
Sum squared resid & 1069.489 & Schwarz criterion & 5.057607 \\
Log likelihood & -321.4432 & Hannan-Quinn criter. & 5.018322 \\
F-statistic & 19.47752 & Durbin-Watson stat & 2.193510 \\
Prob(F-statistic) & $\mathbf{0 . 0 0 0 0 0 0}$ & & \\
\hline
\end{tabular}

Berdasarkan tabel 8, diketahui nilai koefisien determinasi (Adjusted Rsquared) sebesar $\mathrm{R}^{\wedge} 2=0.222681$. Nilai tersebut dapat diartikan CAR dan NPF secara simultan atau bersama-sama mempengaruhi RO sebesar 22,27\%, sisanya sebesar $77,73 \%$ dipengaruhi oleh faktor-faktor lain.

Uji $\mathrm{F}$ bertujuan untuk menguji pengaruh variabel bebas secara bersama-sama atau simultan terhadap variabel tak bebas. Berdasarkan tabel 8 , diketahui nilai Prob. (F-statistics), yakni 0,0000 $<0,05$, maka dapat disimpulkan bahwa seluruh variabel bebas, yakni CAR dan NPF secara simultan, berpengaruh signifikan terhadap variabel ROA.

Berdasarkan tabel 8, diperoleh persamaan regresi linear berganda sebagai berikut.

$Y=3.01+0,012 X_{1}-0.978 X_{2}$

Tabel 9 Kesimpulan Hasil Uji

\begin{tabular}{|c|c|c|c|}
\hline & $\begin{array}{c}\text { Koefisien } \\
\text { regresi }\end{array}$ & Probability & Kesimpulan \\
\hline $\operatorname{CAR}\left(\mathrm{X}_{1}\right) \quad->\mathrm{ROA}(\mathrm{Y})$ & 0,012 & 0.3126 & $\begin{array}{l}\text { CAR berpengaruh positif dan } \\
\text { tidak signifikan terhadap ROA }\end{array}$ \\
\hline $\operatorname{NPF}\left(\mathrm{X}_{2}\right) \quad->\operatorname{ROA}(\mathrm{Y})$ & -0.978 & 0,0000 & $\begin{array}{lr}\text { CAR berpengaruh } & \text { negatif } \\
\text { signifikan } & \text { terhadap } \\
\text { Profitabilitas } & \end{array}$ \\
\hline
\end{tabular}


Hasil uji hipotesis secara simultan menunjukkan bahwa variabel Capital Adequacy Ratio (CAR) dan Non Performing Financing secara bersama-sama berpengaruh terhadap Profitabilitas (ROA).

Hasil uji hipotesis secara parsial menunjukkan bahwa variabel Capital Adequacy Ratio berpengaruh positif namun tidak signifikan terhadap ROA, sehingga dalam hal ini hipotesis 1 ditolak. Penelitian ini sejalan dengan penelitian yang dilakukan oleh Almunawaroh dan Marliana ${ }^{12}$ yang menemukan hasil bahwaCapital Adequacy Ratio tidak berpengaruh signifikan terhadap ROA. Namun penelitian ini berbeda dengan penelitian yang dilakukan oleh Nusantara. ${ }^{13}$

Hasil penelitian yang menunjukan tidak adanya pengaruh signifikan antara Capital Adequacy Ratio dengan ROA ini dapat disebabkan oleh sikap dari manajemen perbankan yang menjaga tingkat Capital Adequacy Ratio perbankan syariah sesuai dengan ketentuan dari bank sentral (BI), sehingga perbankan syariah tidak optimal dalam memanfaatkan modal yang dimilikinya. ${ }^{14}$ Hasil penelitian ini juga didukung oleh penelitian Prasanjaya dan Ramantha ${ }^{15}$, serta Munir ${ }^{16}$ yang menemukan hasil yang serupa.

Hasil uji hipotesis secara parsial menunjukkan bahwa variabel Non Performing Financing berpengaruh negatif dan signifikan terhadap ROA, sehingga dalam hal ini hipotesis 2 diterima.Penelitian ini sejalan dengan penelitian yang dilakukan oleh Rachmat dan Komariah ${ }^{17}$ yang menemukan hasil bahwa Non Performing Financing berpengaruh terhadap ROA.Namun penelitian ini berbeda dengan penelitian yang dilakukan oleh Wibowo ${ }^{18}$ yang menyatakan bahwa Non Performing Financing tidak berpengaruh signifikan terhadap ROA.

Hasil penelitian yang negatif ini menunjukkan tingginya tingkat NPF pada perusahaan perbankan syariah. Besarnya NPF menajdi salah satu penghambat tersalurnya pembiayaan pada perbankan disebabkan timbulnya pembentukan cadangan dana atau biaya bermasalah, sehingga dapat menurunkan laba. Tingkat NPF yang tinggi akan berdampak pada kesehatan bank, dikarenakan semakin tinggi tingkat NPF makan akan semakin besar pula kerugian yang akan dialami bank, dan hal ini akan berakibat pada menurunnya tingkat keuntungan bank dan berkurangnya total 
Rana Fathinah: Pengaruh Capital Adequacy Ratio Dan Non Performing |439

aset bank. Hasil penelitian ini juga didukung oleh penelitian Almunawwaroh dan Marliana ${ }^{19}$ yang menemukan hasil yang serupa.

\section{Kesimpulan}

Secara simultan variabel Capital Adequacy Ratio (CAR) dan Non Performing Financing secara bersama-sama berpengaruh terhadap Profitabilitas (ROA). Namun secara parsial, Capital Adequacy Ratio (CAR) tidak berpengaruh terhadap profitabilitas (ROA), sedangkan Non Performing Financing (NPF) berpengaruh negatif terhadap profitabilitas (ROA). Adapaun keterbatasan dalam penelitian ini, antara lain kondisi perbankan yang cenderung berbeda ini menyebabkan terjadinya rentang angka yang cukup jauh, antar bank. Kondisi ini disebabkan oleh faktor internal yang dimiliki oleh masing masing bank. Dari segi objek peneltian ini masi tergolong terbatas, hanya menggunakan Bank Umum Syariah. Berdasarkan hasil analisis, pembahasan, dan kesimpulan, adapun saran yang dapat diberikan yaitu Bagi pihak manajemen bank dengan merujuk penelitian ini, diharapkan selalu menjaga tingkat kecukupan modalnya, sehingga pada akhirnya dengan tercukupinya tingkat kecukupan modal, kinerja keuangan bank tersebut akan meningkat. Selain itu efisiensi operasional suatu bank merupakan faktor yang paling untuk diperhatikan dalam kaitannya untuk meningkatkan laba suatu bank. disebabkan oleh fungsi bank sebagai pihak intermediasi, efisiensi operasional bank sangat berpengaruh terhadap besar kecilnya laba yang diperoleh bank. semakin efisien operasional bank, maka laba yang diperoleh bank tersebut akan semakin besar. Dengan demikian, bagi manajemen bank sangat penting untuk memperhatikan dan mengontrol pergerakan rasio ini agar bank selalu berada pada tingkat efisiensi yang dapat menghasilkan laba yang optimal. Bagi peneliti selanjutnya di harapkan dapat menambahkan variabel independen lain seperti FDR, BOPO sebagai variabel dependen.

\section{Endnote}

${ }^{1}$ www.ojk.go.id

${ }^{2}$ OJK, 2019.

${ }^{3}$ D. Lukman. Manajemen Perbankan. (Ghalia Indonesia : Jakarta, 2009).

${ }^{4}$ Y. Sari. Pengaruh Profitabilitas, Kecukupan Modal dan Likuiditas Terhadap Harga Saham (Perusahaan Perbankan yang Terdaftar di BEI). Jurnal Akuntansi, Vol. 1(1), tahun 2003. 
${ }^{5}$ Rahajeng Kusumo Hastuti, Perbankan Syariah Masih Sulit Bersaing Dengan Konvensional. Diakses https://www.cnbcindonesia.com/syariah/20190607133414-29-77037/perbankan-syariahmasih-sulit-bersaing-dengan-konvensional, pada tanggal 10 November 2020.

${ }^{6}$ R. D. Priantana \& Zulfia. Pengaruh Rasio Kecukupan Modal, Non Performing Loan, dan Tingkat Likuiditas Terhadap Profitabilitas Perbankan yang Terdaftar di Bursa Efek Indonesia. Jurnal Akuntansi dan Keuangan, Vol. 1(1), tahun 2011.

${ }^{7}$ J.E, Biegel. Statistic in Forecasting. Management International. (United Kingdom, 1999)

${ }^{8}$ V, Rivai. Credit Management Handbook : Manajemen Perkreditan Cara-cara Mudah Menganalisis Kredit. (PT. Rajagrafindo Persada : Jakarta, 2013).

${ }^{9}$ Kasmir. Analisis Laporan Keuangan. (Raja Grafindo Persada : Jakarta, 2011).

${ }^{10}$ I. Sakti. Modul Eviews 9: Analisis Regresi Data Panel Menggunakan Eviews. (Universitas Esa Unggul : Jakarta, 2018)

${ }^{11}$ I. Ghozali. Aplikasi Analisis Multivariate dengan Program SPSS. BP. (UNDIP: Semarang, 2011)

${ }^{12}$ M. Almunawwaroh, \& R. Marliana. Pengaruh CAR, NPF dan FDR Terhadap Profitabilitas Bank Syariah di Indonesia. Amwaluna, 2(1): 1-17, 2018.

13 Ibid.

${ }^{14}$ L. Widyaningrum, \& D.F. Septiarini. Pengaruh CAR, NPF, FDR, dan OER terhadap ROA pada bank pembiayaan rakyat syariah di Indonesia periode januari 2009 hingga Mei 2014. JESTT, 2(12): 970-985, 2015.

15 A.A. Y. Prasanjaya, \& I.W. Ramantha. Analisis Pengaruh Rasio CAR, BOPO, LDR dan Ukuran Perusahaan Terhadap Profitabilitas Bank Yang Terdaftar di BEI. E-Journal Akuntansi, (S.I). v.4, n.1, p. 230-245, 2013.

16 M. Munir. Analisis Pengaruh CAR, NPF, FDR dan Inflasi Terhadap Profitabilitas Perbankan Syariah di Indonesia. Journal of Islamic Economics, Finance, and Banking, Vol.1, No 1\&2, pp. 89-98, 2018.

${ }^{17}$ A. B. Rachmat, \& E. V. Komariah. Faktor-Faktor Yang Mempengaruhi Profitabilitas Pada Bank Umum Syariah Periode 2010-2015. Jurnal Online Insan Akuntan, Vol.2, No.1, hal.17-34, 2017.

18 E. S. Wibowo. Analisis Pengaruh Suku Bunga, Inflasi, CAR, BOPO, NPF Terhadap Profitabilitas Bank Syariah. Journal Of Management. Volume 2, Nomor 2, 1-10 http://ejournals1.undip.ac.id/index.php/djom ISSN (Online): 2337- 3792, 2013.

${ }^{19}$ M. Almunawwaroh, \& R. Marliana. Pengaruh CAR, NPF dan FDR Terhadap Profitabilitas Bank Syariah di Indonesia. Amwaluna, 2(1): 1-17, 2018. 
Rana Fathinah: Pengaruh Capital Adequacy Ratio Dan Non Performing |441

\section{Daftar Pustaka}

Almunawwaroh, M., \& Marliana, R. (2018). Pengaruh CAR, NPF dan FDR Terhadap Profitabilitas Bank Syariah di Indonesia. Amwaluna, 2(1): 1-17.

Biegel. J. E (1999). Statistic in Forecasting.Management International. United Kingdom.

Ghozali, I. (2011). Aplikasi Analisis Multivariate dengan Program SPSS.BP. UNDIP: Semarang.

Jama'an. (2008). Pengaruh Mekanisme Corporate Givernance, dan Kualitas Kantor Akuntan Publik Terhadap Integritas Informasi Laporan Keuangan (Studi Pada Perusahaan Publik di BEI). Tesis Program Studi Magister Sain Akuntansi Universitas Diponegoro, Semarang.

Kasmir. (2011). Analisis Laporan Keuangan. Raja Grafindo Persada: Jakarta.

Lukman, D. (2009). Manajemen Perbankan. Ghalia Indonesia: Jakarta.

Moussa, M. (2012). Bank-specific and Macroeconomic Determinants of Bank Profitability: Case of Turkey. Thesis Master of Science in Banking and Finance Eastern Mediterranean University Gazimağusa, North Cyprus.

Munir, M. (2018). Analisis Pengaruh CAR, NPF, FDR dan Inflasi Terhadap Profitabilitas Perbankan Syariah di Indonesia.Journal of Islamic Economics, Finance, and Banking, Vol.1, No 1\&2, pp. 89-98.

Nusantara. A. B. (2009). Analisis Pengaruh NPL, CAR, LDR, dan BOPO Terhadap Profitabilitas Bank(Perbandingan Bank Umum Go Publik dan Bank Umum Non Go Publik di Indonesia Periode Tahun 2005- 2007). Tesis tidak diterbitkan. Semarang: Program Studi Magister Manajemen Universitas Diponegoro.

Peraturan Otoritas Jasa Keuangan Republik Indonesia. (2017).

Prasanjaya, A.A.Y., \& Ramantha, I.W. (2013). Analisis Pengaruh Rasio CAR, BOPO, LDR dan Ukuran Perusahaan Terhadap Profitabilitas Bank Yang Terdaftar di BEI. E-Journal Akuntansi, (S.I). v.4, n.1, p. 230-245.

Priantana, R. D., \& Zulfia. (2011). Pengaruh Rasio Kecukupan Modal, Non Performing Loan, dan Tingkat Likuiditas Terhadap Profitabilitas Perbankan 
442 AT-TAWASSUTH: Jurnal Ekonomi Islam, Volume V No. 2

Juli - Desember 2020: 423 - 442

yang Terdaftar di Bursa Efek Indonesia. Jurnal Akuntansi dan Keuangan, Vol. $1(1)$.

Rachmat, A. B., \& Komariah, E. V. (2017). Faktor-Faktor Yang Mempengaruhi Profitabilitas Pada Bank Umum Syariah Periode 2010-2015. Jurnal Online Insan Akuntan, Vol.2, No.1, hal.17-34.

Rivai, V. (2013). Credit Management Handbook : Manajemen Perkreditan Caracara Mudah Menganalisis Kredit. PT. Rajagrafindo Persada : Jakarta.

Sakti, I . (2018). Modul Eviews 9: Ananlisis Regresi Data Panel Menggunakan Eviews. Universitas Esa Unggul : Jakarta.

Sari, Y. (2013). Pengaruh Profitabilitas, Kecukupan Modal dan Likuiditas Terhadap Harga Saham (Perusahaan Perbankan yang Terdaftar di BEI). Jurnal Akuntansi, Vol. 1(1).

Wibowo, E, S. (2013). Analisis Pengaruh Suku Bunga, Inflasi, CAR, BOPO, NPF Terhadap Profitabilitas Bank Syariah. Journal Of Management. Volume 2, Nomor 2, 1-10 http://ejournal-s1.undip.ac.id/index.php/djom ISSN (Online): 2337- 3792 .

Widyaningrum, L. \& Septiarini DF. (2015). Pengaruh CAR, NPF, FDR, dan OER Terhadap ROA Pada Bank Pembiayaan Rakyat Syariah Di Indonesia Periode Januari 2009 Hingga Mei 2014. JESTT, 2(12): 970-985.

www.bi.go.id

www.ojk.go.id 